\title{
Diyabetik Hastalarda Amputasyon Sonrası Yara İyileşmesi ve Bakım
}

\author{
Wound Healing and Care After Amputation in Diabetic Patients
}

\section{Seda AKUTAY, Özlem Ceyhan}

Erciyes Üniversitesi Sağlık Bilimleri Fakültesi, Hemşirelik ABD, Cerrahi Hastalıkları Hemşireliği BD, KAYSERİ, Türkiye

\author{
Yazışma Adresi / Correspondence:
}

\author{
Özlem Ceyhan
}

Erciyes Üniversitesi Sağlık Bilimleri Fakültesi, 38039, Melikgazi/Kayseri

T: +90542667 6504 E-mail: ozlemceyhan06@gmail.com

Geliş Tarihi / Received : 12.12.2018 Kabul Tarihi / Accepted : 21.02.2019

$\ddot{\mathrm{O} z}$

Diyabette bozulan glikoz metabolizması dokular üzerinde yıkıcı etkilere sahiptir. Uluslararası Diyabet Federasyonu’nun (IDF) verilerine göre 2017 yllinda dünya genelindeki 425 milyon diyabetli bireyden yaklașık 6.7 milyonu Türk toplumunda bulunmaktadır. Diyabetik ayak, yüksek kan glikozunun sinir ve damar hasarı gibi yıkıcı etkileri sonucunda ortaya çıkan alt ekstremitelerde görülen minör bir travmayı takiben gelişen ülser, enfeksiyon ve derin doku hasarıdır. Diyabetik ayak dünya genelinde her 20 saniyede bir ayak kaybına neden olmaktadır. Ayak yaraları diyabetik popülasyonda $\% 80$ oranında majör amputasyonla sonuçlanabilen durumlardır. Yara bakımı tüm cerrahi hastalarında olduğu gibi diyabetik amputasyon geçiren bireylerde de enfeksiyon ve yeniden amputasyonları önlemek açısından önemlidir. Diyabete bağlı bozulan yara iyileşmesi amputasyon sonrası süreçte de bireyi etkilemektedir. Steril teknikle yapılacak pansuman, negatif basınçlı yara tedavisi gibi uygulamalar iyileşmeyi destekleyerek yara iyileşme sürecini hızlandırabilecek yöntemlerdir. Bu makale diyabetik hastalarda amputasyon sonrası yara iyileşme süreci ve yara bakımı konusunda farkındalık yaratmak amacıyla yazılmıștır. ( Sakarya Tip Dergisi 2019, 9(1):11-15 )

Anahtar Amputasyon; diyabetik ayak; yara iyileşmesi

Kelimeler

The impaired glucose metabolism in diabetes has destructive effects on tissues. According to the International Diabetes Federation (IDF) data in 2017, approximately 6.7 million out of 425 million diabetic patients worldwide are in the Turkish population. Diabetic foot is a ulcer, infection and deep tissue damage following minor trauma in lower extremities resulting from destructive effects of high blood glucose, nerve and vascular damage. Diabetic foot causes loss of foot every 20 seconds through out the world. Foot wounds are those that can result in $80 \%$ of the major amputation in the diabetic population.As with all surgical patients, wound care is important to prevent infection and re-amputations in individuals with diabetic amputation. Worsening wound healing due to diabetes affects the individual in the post-amputation period.Applications such as dressing with sterile technique, negative pressure wound treatment, injection of growth factors to the wound site, hyperbaric oxygen therapy are methods that can accelerate the wound healing process by supporting healing. This article was written to raise awareness about the factors affecting wound healing processes in amputations with diabetic patients. (Sakarya Med J 2019, 9(1):11-15).

Keywords Amputation; diabetic foot; wound healing 


\section{GIIRIŞ}

Diyabetes mellitus, pankreastaki beta hücrelerinden insülin hormunu üretiminde ya da dokulardaki insülin kullanımında bir bozukluktan kaynaklanan karbonhidrat, yağ ve protein metabolizmalarındaki değişikliklerle karakterize, kronik bir hastalıktır. ${ }^{1}$ Uluslararası Diyabet Federasyonu'nun (IDF) verilerine göre 2017 yılında dünya genelinde 425 milyon diyabetli birey bulunmakla birlikte bu sayının 2045 yılında 629 milyona ulaşacağı tahmin edilmektedir. Yine aynı verilerde Türk toplumunda diyabet görülme sıklığı \%12.8 ve diyabetli insan sayısı yaklaşık 6.7 milyon olarak belirtilmiştir. Diyabete bağlı küresel sağlık harcamasının ise 2017 yılında 727 milyar dolar olduğu belirlenmiştir. ${ }^{2}$ Bakım maliyeti bu kadar yüksek olan diyabette ayak yaraları yaygın görülen bir komplikasyon olup dünyada her 20 saniyede bir ayak kaybına neden olmaktadır. ${ }^{3}$

\section{Diyabetik Ayak Yaraları}

Diyabetik ayak genellikle nöropatik, iskemik ve nöro-iskemik olarak sınıflandırılmaktadır. Nöropatik ayak, diyabetik nöropatinin motor, duyusal ve otonomik bileşenlerinin bir sonucudur. Motor nöropatide, ayağın intrinsik kaslarının ilerleyici atrofisine bağlı ayak deformiteleri ortaya çıkmaktadır. Duyusal nöropatide ağrı algısı bozulduğu için ayak travmalara ve yara oluşumuna karşı korunmasız kalmaktadır. Otonomik nöropatide cilt kuru ve çatlak bir hal aldığı için diyabetik ayak yaralarının oluşumu risk faktörüdür. İskemik ayak hızlı ve ilerleyici bir durumdur ve alt ekstremitelerde ayak enfeksiyonu riskini arttırmaktadır. ${ }^{4}$ Nöro-iskemik ayakta ise hem nöropatik hem de iskemik olaylar birlikte görülmektedir.

\section{Diyabetik Ayak Yaraları ve Amputasyon}

Diyabetik ayak, periferik nöropatiye bağlı sinir hasarı ve periferik damarlardaki ateroskleroz gibi nedenlerle alt ekstremitelerde görülen minör bir travmaya bağlı gelişen ülser, enfeksiyon ve derin doku hasarıdır., Diyabetik ayak yaralarından \%60 oranında nöropati sorumludur. ${ }^{7}$ Diyabetik ayak görülme sıklığı erkeklerde ve Tip 2 diyabet hastalarında daha fazladır. ${ }^{8}$ Diyabetik hastalardaki nöro- pati, iskemi ve immünsüpresyon gibi nedenler dirençli enfeksiyonların gelişmesine neden olmaktadır. Bu enfeksiyonların kemiğe kadar ilerlemesi sıklıkla amputasyona ve hatta ölüme neden olabilmektedir.,10 Amputasyonlar için tanımlanan en yaygın endikasyonlar gangren, enfeksiyon ve iyileşmeyen yaralardır. ${ }^{11}$ Ülkemizde yapılan amputasyon sayısı Sağlık Bakanlığı verilerine göre yılda yaklaşık 12000 civarındadır. ${ }^{12}$ Travmatik nedenler dışındaki amputasyonların \%50'si diyabete bağlı olarak gerçekleşmektedir. ${ }^{6}$ Diyabetik amputasyonların \%45-85'i önlenebilir nedenlerden kaynaklanmaktadır. ${ }^{13,14}$ Nöropati, enfeksiyon ve iskeminin iyi yönetilememesinden kaynaklanan ayak yaraları diyabetik popülasyonda $\% 80$ oranında majör amputasyonla sonuçlanabilen durumlardır. ${ }^{13}$

\section{Diyabette Yara İyileşmesi}

Yara iyileşmesi birbiriyle ilişkili hemostaz, inflamasyon, epitel doku oluşumu ve oluşan dokunun yeniden şekillenmesi gibi birçok olayın bir arada gerçekleştiği bir süreç olduğu için, bu süreçte meydana gelecek değişiklikler yaranın kronikleşmesine ve iyileşmenin gecikmesine yol açabilmektedir. ${ }^{15}$ Normal yara iyileşmesinde enflamatuar hücrelerin yara yatağına göçüyle uyarılan büyüme faktörlerinin etkisiyle meydana gelen endotel hücre proliferasyonu, anjiogenezis, kollajen sentezi gibi olaylar diyabette değişikliğe uğradığı için yara iyileşmesini geciktirebilmektedir. $^{16,17}$

Diyabetik hastalarda gelişen mikrovasküler (nöropati, retinopati, nefropati) ve makrovasküler (koroner arter hastalığı, perifer arter hastalığı, serebrovasküler hastalıklar) komplikasyonların temelinde yatan neden hiperglisemidir. ${ }^{18}$ Hiperglisemi diyabetik hastalarda lökosit fonksiyonunu bozarak nötrofil ve makrofajların yaraya yetersiz göçüne neden olmaktadır. Bu tür hücresel değişiklikler diyabetik bireyleri yara enfeksiyonu riskine yatkın hale getirebilmektedir. ${ }^{12}$ Ayrıca hastaların bozulan glikoz metabolizmaları normal koşullarda hipoksi durumunda hücreleri uyaran, düşük oksijen basıncına karşı doku ve hücrelerin adaptasyonunu sağlayan, hücre çoğalması, anjiogenezis 
gibi işlevlere sahip olan hipoksiyle indüklenen faktör-1 (HIF-1) proteininin fonksiyonunu bozarak tüm iyileşme süreçlerini etkileyen bir yalancı hipoksiye neden olmaktadır. ${ }^{4,19}$ Bunun yanı sıra hiperglisemi kollajen sentezini de bozarak yaranın kapanmasını geciktirebilmektedir. ${ }^{16}$ Tüm bu sebepler diyabette yara iyileşmesini etkilemektedir.

\section{Diyabetik Amputasyon Sonrası}

\section{Yara İyileşmesinde Bakım}

Amputasyon süreci bireyi ve ailesini etkileyen kompleks bir süreçtir. Bu süreçte bireye verilecek olan bakım, hem bireyin cerrahi işleme bağlı oluşan yara bakım sürecini hem de ağrı yönetimi, postoperatif komplikasyonların takibi ve önlenmesi, eğitim, hasta güvenliği, mobilizasyon, beslenme ve rehabilitasyon gibi hasta gereksinimlerinden doğan çok yönlü bir süreci kapsamalıdır.

Yara bakımı tüm cerrahi hastalarında olduğu gibi diyabetik amputasyon geçiren bireylerde de enfeksiyon ve yeniden amputasyonları önlemek açısından son derece önemlidir. Diyabete bağlı bozulan yara iyileşme süreci amputasyon sonrasında da bireyi etkilemektedir. Amputasyon güdüğü yüksek kan glukozu, yetersiz kan dolaşımı ve zayıflamış bağışıklık sistemi gibi nedenlerle sıklıkla enfekte olmaktadır. ${ }^{20}$ Yara alanının kanlanması ve oksijenlenmesinin desteklenmesi, yaranın enfeksiyon ve travmalardan korunmas1 iyileşme sürecinde önemlidir. ${ }^{21}$

Yara iyileşmesinde hücrelere gereksinim duyduğu enerjiyi sağlamak için beslenme de bir diğer önemli faktördür. Karbonhidrat, yağ, protein, vitamin ve minerallerin dengeli alımı hücre yenilenmesi ve doku onarımını sağlarken, besin eksiklikleri yara iyileşmesinde gecikmeye neden olarak yaranın kapanmasında gecikme ve enfeksiyona neden olabilir. Yara iyileşmesinde; enerji kaynağ 1 olarak karbonhidratlara, hücre membranının yenilenmesi için yağlara, dokunun direncini sağlayacak kollajenin yapımı ve immün sistemi güçlendirmek için protein, vitamin ve minerallere ihtiyaç duyulmaktadır. ${ }^{22,23}$ Armstrong ve arkadaşlarının yaptığı randomize kontrollü bir çalışmada, diyabetik ayak ülserinde yara iyileşmesine protein desteğinin etkisini incelemişler ve 270 hastaya 16 hafta boyunca verilen protein destek içeceğinin yara iyileşmesinde hızlanma sağladığını saptanmışlardır. ${ }^{24}$ Diyabetik ayak ülseri olan 57 hastayla yapılmış bir başka randomize kontrollü çalışmada magnezyum ve E vitamini desteğinin ülser büyüklüğü üzerinde olumlu etkisi olduğu bulunmuştur. ${ }^{25}$

Amputasyon sonrası süreçte yara yeri; kanama, enfeksiyon, ödem ve travma açısından gözlenmelidir. Vital bulgular ameliyat sonrası dönemde kanama ve enfeksiyon bulguları açısından değerlendirilmeli, nörovasküler değerlendirme (duyu, ödem, ağrı, nabız, hareket, cilt rengi ve 1Sısı) kalan ekstremite (güdük) dolaşımını sağlamak için yakından takip edilmelidir.

Ameliyat sonrası süreçte aseptik koşullara uygun gerçekleştirilen pansuman teknikleri, negatif basınçlı yara kapatma tedavisi gibi tedaviler iyileşmeyi destekleyerek yara iyileşme sürecini hızlandırır. Böylece güdüğün proteze hazırlanması kolaylaştırılmış olur. Steril tekniklere uyularak gerçekleştirilen güdük bakımı hızlı iyileşmeye ve güdüğün fonksiyonlarını daha kısa sürede kazanmasına yardımcı olmaktadır. Diz altı seviyeden ampute edilen 20 hastanın dahil edildiği, amputasyon güdüğünde ödem kontrolünün sağlanmasında elastik bandaj uygulaması ile bandajlamaya ek olarak masaj ve güdüğün elevasyona alındığı kompleks boşaltıcı terapi (KBT) yönteminin karşılaştırıldığı bir çalışmada KBT uygulanan hastalarda kalıcı proteze geçişin daha kısa sürede gerçekleștiği saptanmıştır. ${ }^{26}$

Negatif basınçlı yara tedavisi (NBYT) yaradaki boşluğu dolduran özel bir sünger ve bir aspiratör yardımıla aralıklı ya da devamlı olarak yaradaki fazla eksudayı uzaklaştıran ve yaranın hızla iyileşmesini sağlayan bir yöntemdir. Yapılan çalışmalarda diyabetik hastalarda amputasyon sonrası yara iyileşmesinde kullanılan NBYT’nin standart nemli pansumana oranla daha hızlı iyileşmeye katkı sağladığ 1 ve birçok klinisyen tarafından standart nemli pansumana göre tercih edildiği görülmüştür. ${ }^{27-29}$ 
Kronik yaralarda NBYT tedavisinin etkinliğini ölçen bir çalışmada diyabetik ayak nedeniyle amputasyon yapılan 2 hastada NBYT sonrası enfeksiyon bulgularının gerilediği ve yaraların kapandığ 1 görülmüştür. ${ }^{30}$ Diyabetik ayak ülseri nedeniyle kısmi ayak amputasyonu yapılan 65 hastada yapılan NBYT ile klasik nemli pansumanın karşılaştırıldığı retrospektif bir çalışmada NBYT ile yara bakımında \%90’a varan granülasyon dokusuyla daha başarılı sonuçların elde edildiği görülmüştür. ${ }^{31}$ Bir diğer çalışmada diyabetik ayak yarası olan 40 hastanın yarısına NBYT ve debridman, yarısına ise pansuman ve debridman uygulanmıştır. NBYT uygulanan hastaların yaralarının daha kısa sürede iyileştiği ve amputasyon oranlarının daha az olduğu görülmüştür. ${ }^{32}$

Diyabetik yaraların tedavisinde aktif yara kapama tekniği olarak, negatif basınçlı yara kapatma tedavisinin yanı sıra, hiperbarik oksijen tedavisi, çeşitli debridman tedavileri (Maggot tedavisi, enzimatik debridman), yaraya büyüme faktörlerinin enjeksiyonu ve greft uygulama gibi çeşitli tedaviler de kullanılmaktadır. ${ }^{33}$

Hiperbarik oksijen tedavisi, yaraya 1.5 ila 3 atmosfer basıncında 1-2 saate kadar değișen sürelerde $\% 100$ oksijen verilmesi esasına dayanan tedavi şeklidir. Etki mekanizması tam olarak anlaşılamasa da ilk teoriler dokudaki arteriyel oksijen basıncı artışını sağlayarak vazokonstriksiyona neden olduğu yönündedir. Böylece venöz sistemde sıvı emilimi artar ve ödem azalır. Bu durum yara bölgesinde dokunun perfüzyonunu artırarak yara iyileşmesini kolaylaştırır. ${ }^{34}$ Hiperbarik oksijen tedavisinin ayrıca diyabette bozulan anjiogenezisi artırarak iyileşmeye yardımcı olduğu düşünülmektedir. Enfekte diyabetik ayak nedeniyle antibiyotik tedavisine ek olarak hiperbarik oksijen tedavisi alan 30 hastayla yapılan bir çalışmada hastaların 19 unda klinik iyileşme görülürken, 11 hastada etkin tedavi sağlanamadığı belirlenmiştir. ${ }^{35}$ Diyabetik ayak yarası olan ve hiperbarik oksijen tedavisi uygulanan 48 hastanın tedavi öncesi ve sonrası yara iyileşmesinde İnsüline Benzer Büyüme Faktörü-1 (IGF-1) seviyelerindeki değişimin incelendiği bir çalışmada, 40 hastada tam iyileşme sağlandığı ve iyileşen grupta büyüme faktörlerinin anlamlı şekilde yüksek bulunduğu görülmüştür. ${ }^{36}$

Maggot tedavisi, laboratuvar koşullarında steril olarak çoğaltılan Lucilia sericata türü sineğin larvalarının yara tedavisinde kullanılmasıdır. Maggot tedavisi yara iyileşmesine 3 yolla etki eder. İlk olarak larvalar yara yüzeyindeki nekrotik ve enfekte olmuş dokuyu sindirerek mekanik debridman sağlarlar. İkincisi salgıladıkları sindirim enzimleri sayesinde enzimatik debridman yaparak yarayı mikroorganizmalardan korurlar. Son olarak larvaların yara yüzeyindeki hareketleri mekanik uyarı oluşturarak inflamatuar hücrelerin yara yerine göçünü arttırarak yara iyileşmesine katkıda bulunur. Diyabetik ayak yarası olan 23 hasta üzerinde yapılan bir çalışmada maggot tedavisinin iyileşme üzerinde olumlu sonuçlar oluşturduğu görülmüştür. ${ }^{37}$

\section{SONUÇ}

Diyabette yara iyileşmesi birçok faktöre bağlı olarak gecikmektedir. Bu durum cerrahi bir girişim olan amputasyon sürecinde de iyileşmenin gecikmesine, bireyde çeşitli yara komplikasyonlarının gelişmesine yol açmaktadır. Bu durum, ameliyat sonrası süreçte güdüğün proteze hazırlanmasını geciktirerek bireyin daha uzun süre hastanede yatmasına ve tekrarlı amputasyonlara neden olabilmektedir. Ameliyat sonrası süreçte uygun yara bakım tekniklerini kullanarak planlı bir bakım yapılması bireyin iyileşme sürecini ve yaşam kalitesini etkilemektedir. Bunun için diyabetik bireylerde amputasyon sonrası yara bakım teknikleriyle ilgili daha çok çalışma yapılmasına ve bu konuda literatür oluşturulmasına gerek duyulmaktadır.

Bu makale 13.Ulusal Yara Kongresine poster bildiri olarak sunulmuştur. 


\section{Sakarya Tip Dergisi 2019;9(1):11-15}

AKUTAY ve Ark. Diyabetik Hastalarda Amputasyon Sonrası Yara İyileşmesi ve Bakım

\section{Kaynaklar}

1. Guyton A.C, Hall J.E. İnsülin, Glukagon ve DibetesMellitus, (Çeviren:Sanl Sadi Kurdak), İçinde:Tibbi Fizyoloji. 12.baskı. İstanbul: Nobel Tip Kitabevleri; 2013.p. 950.

2. Cho NH, Shaw JE, Karuranga S, Huang Y, daRochaFernandes JD, Ohlrogge AW, Malanda B. IDF Diabetes atlas: globalestimates of diabetes prevalence for 2017 andprojectionsfor 2045. Diabetes Research and Clinical Practice 2018;138:271-281.

3. Ayanoğlu S. Diyabetik ayak hastalı̆̆ına güncel yaklaşımlar. Okmeydanı Tip Dergisi 2015; 31(Ek sayt):63-71.

4. Meloni M, Izzo V, Giurato L, Uccioli L. A Complication of the complications: the complexity of pathogenesis and the role of co-morbidities in the diabetic foot syndrome. front diabetes. Basel, Karger 2018;26:19-32.

5. Durgun O, Gökmen Durgun A, Özyardımcı Ersoy C, Almacıŏglu S, Karadayı D, Özkaya G. ve ark. Diyabetik ayak gelișmiş olgularda amputasyon gerekliliğini belirleyen faktörlerin retrospektif olarak incelenmesi. Uludağ Üniversitesi Tip Fakültesi Dergisi 2012;38(2):59-62.

6. Olgun N, Eti Aslan F, Coşansu G, Çelik S. Diabetes Mellitus. İçinde: Dahili ve Cerrahi Hastalıklarda Bakım. Karadakovan A. ve Eti Aslan F (editörler). 4.Baskı, 2.cilt. Ankara: Akademisyen Kitabevi; 2017.p.795.

7. Clayton W Jr and Elasy TA. A Review of the pathophysiology, classification, and treatment of foot ulcers in diabetic patients. Clinical Diabetes 2009; 27(2): 5258 .

8. Zhang P, Lu J, Jing Y, Tang S, Zhu D, Bi Y. Global epidemiology of diabeticfootulceration: a systematic review and meta-analysis. Annals of Medicine 2017;49(2):106-116.

9. Lipsky BA, Johannes RS, Weigelt JA, Derby KG, Sun X, Tabak YP. Developingand validating a risk score forlower-extremity amputation in patients hospitalized for a diabetic foot infection. DiabetesCare 2011;34:1695-1700

10. Costa RHR, Cardoso NA, Procópia RJ, Navarro TP, Dardik A, deLoiolaCisneros L. Diabetic foot ulcer carries high amputation and mortalityrates, particularly in the presence of advancedage, peripheral artery disease and anemia. diabetes \& metabolic syndrome. ClinicalResearch $\prec$ Review 2017;11:583-587.

11. Piaggesi A, Apelqvist J. Front Diabetes: The Diabetic Foot Syndrome. Basel: Karger, 2018.p.1-18.

12. Saltoğlu N, Kılıçoğlu Ö, Baktıroğlu S, Oșar Siva Z, Aktas S, Altındas M.ve ark. Diyabetik ayak yarası ve infeksiyonunun tanısı, tedavisi ve önlenmesi: ulusal uzlașı raporu. Klinik Dergisi 2015;28(1):2-34.

13. Vartanian SM, Robinson KD, Ofili K, Eichler CM, Hiramoto JS, Reyzelman AM, Conte MS. Outcomes of neuroischemic wounds treatedby a multidisciplinary amputation prevention service. Annals of Vascular Surgery 2015; 29(3):534-542.

14. Canavan RJ, Kelly WF, Unwin NC, Connolly VM. Diabetes and nondiabetes related lower extremity mutation incidence before and after the introduction of better organized diabetes foot care. Diabetes Care 2008; 31:459-463.

15. Bilen H. Yara yönetiminde alternatif yöntemler ve yenilikler. Türkiye Klinikleri J Endocrin-Special Topics 2015; 8(3):50-57.

16. Blakytny $R$ and Jude E. Themolecularbiology of chronic wounds and delayed healing in diabetes. Diabetic Medicine 2006;23(6):594-608.

17. Rebolledo FA, Soto JT, de la Peña J.E. The pathogenesis of the diabetic foot ulcer: prevention and management. In: Dinh T (eds), Global Perspective on Diabetic Foot Ulcerations. In Tech; 2011.p.155-182.

18. Özkan S, Eser H.R. Diyabetik ayak ve cerrahi yaklașım.1.Uluslararast Sağlık Bilimleri ve Yaşam Kongresi Bildiri Kitabı. Burdur: 2018; 319-325.

19. Demirel SH ve Çetinkaya S. Hipoksiyle indüklenen faktör-1: hücrenin hipoksiye fizyolojik ve patolojik cevabi. Sakarya Tip Dergisi 2014;4(4):171-177.

20. Ashraff S, Siddiqui MA, Santos D, Carline T. Complications of stump healing among diabetic population. Turkish J Endocrinology and Metabolism 2018; 22:91-97.
21. Schreiber ML. Lower limb amputation:postoperative nursing care and considerations. Med Surg Nursing 2017; 26(4): 274-277.

22. Kutluay Köklü H. ve Uğar Çankal DA.Yara İyileșmesini Etkileyen Faktörler İçerisinde Beslenmenin Yeri. Atatürk Üniversitesi Diș Hekimliği Fakültesi Dergisi 2013;7:135-141.

23. Dryden SV, Shoemaker WG ,Kim JH. Wound Management And Nutrition For Optimal Wound Healing. Atlas Of The Oral And Maxillofacial Surgery Clinics Of North America 2013; 21(1):37-47.

24. Armstrong DG, Hanft JR, Driver VR, ve ark. Effect of oral nutritional supplementation on wound healing in diabetic foot ulcers: a prospective randomized controlled trial. Diabet Med. 2014;31(9):1069-77.

25. Afzali H, Caferi Kashi AH, Momen-Heravi M, Razzaghi R, Amirani E, Bahmani F, Gilasi $H R$, Asemi $Z$. The effects of magnesium and vitamin $E$ co-supplementation on wound healing and metabolic status in patients with diabetic foot ulcer: A randomized, double-blind, placebo controlled trial. Wound Rep Reg.. https://doi.org/10.1111/wrr.12701; 28 Ocak 2019.

26. Topuz S, Ülger Ö, Yurt Y, Bayramlar K, Erbahçeci F, Sener G, Yetkin H. Diz altı amputelerde farkl postoperatif ödem kontrol yöntemlerinin etkinliğinin karșllaștırllması. Türk Fizyoterapi ve Rehabilitasyon Dergisi 2015;24 (1):64-70.

27. Armstrong DG, Fiorito JL, Leykum BJ, Mills JL. Metatarsal Head Resecion as a Curative Procedure in Patients with Diabetes Mellitus and Neuropathic Fore foot Wounds. Foot \& Ankle Specialist 2012;5(4):235-240.

28. Akyolcu N. Yara iyileșmesi ve hemșirelik bakımı. Aksoy G, Kanan N, Akyolcu N, editör. Cerrahi Hemșireliği. 2. Basl. Adana: Nobel Tip Kitabevleri 2017.p.79-114.

29. Sepúlveda G, Espíndola M, Maureira M, Sepúlveda E, Fernández JI, Oliva C, Sanhueza A, Vial M, Manterola C. Negative-pressure wound therapy versus standard wound dressing in the treatment of diabetic foot amputation. A randomised controlled trial. Cirugía Española 2009;86(3):171-177.

30. Aygün H, Çakar A, Atilla HA, Irlayıcı TB, Aytekin MN, Ağır İ, İslam C. Zor iyileșen alt ekstremite yaralarınin tedavisinde negatif basinçl yara tedavi yönteminin etkinliği ve sonuçları. Ankara Medical Journal 2013;13(1):16-21.

31. Sükür E, Akar A, Uyar AC, Cicekli O, Kochai A, Turker M, Topcu, HN. Vacuum-assisted closure versus moist dressings in the treatment of diabetic wound ulcer safter partial foot amputation: A retrospectiv eanalysis in 65 patients. Journal of Orthopaedic Surgery 2018;26(3):1-5.

32. Novak A, Khan WS, Palmer J. The evidence-based principles of negative pressure wound therapy in trauma \& orthopedics. The Open Orthopaedics Journal 2014; 8:168-177.

33. ErdoğanB. Diyabetik ayakta yara bakımı ve yara bakımı malzemeleri. Türkiye Klinikleri J Gen Surg-Special Topics 2010;3(1):88-93.

34. Murphy PS and Evans GRD. Advancces in Wound Healing: AReview of Current Wound Healing Products. Plastic Surgery İnternational 2012; doi: 10.1155/2012/190436

35. Mert G, Metin S, Yildız Ș, Karakuzu E, Çakmak T. Diyabetik ayak ülseri nedeniyle hiperbarik oksijen tedavisi planlanan hastalarda yara kültürü ile tespit edilen enfeksiyon ajanlar. TAF Preventive Medicine Bulletin 2012;11(2):205-210.

36. Aydın F, Kaya A, Karakuzu C, Kumbaracı M, Karapınar L, İncesu M. Diyabetik Ayak ÜLserinde Hiperbarik Oksijen Tedavisinin Etkisinin Igf-1 İle Araștırlmast.5.Ulusal Sualtı Hekimliği ve Hiperbarik Tip Kongresi ve Su Sporları Sempozyumu Kongre Kitabı Sözel Bildiri 2012: İstanbul.p.92-98

37. Tanyüksel M, Koru Ö, Araz E, Kılbaş HZG, Yildız Ş, Alaca R. Kronik yaraların tedavisinde steril Luciliasericata larva uygulamalar. GulhaneMed J 2014;56(4):218-22. 